\title{
Discourse Analysis on Historical Artifacts in Candi Panataran, Blitar-East Java
}

\author{
Lilly Harmawan Setiono and Setiawan Sabana
}

\begin{abstract}
The damages to our historical and cultural artifacts are increasing before we could learn from them. Lately, natural deterioration or disasters, ignorance, lack of attention, and our neglect are increasing, making the rate of their deterioration even faster. Take candi Panataran, for example. In only few years, the shapes and conditions of the reliefs degraded so much that what used to be apparent forms became unrecognizable. The efforts to understand the past and gain insights for present and future reference are still very low. Perhaps if approaches to these artifacts were extended, reformed and more interesting findings are found, the willingness to care increases. After all, the responsibility to care for historical and cultural artifact does not belong to archaeologists, anthropologists, historians alone, but have extended to many other disciplines. This paper wishes to explore artifacts from visual art perspective, using Foucault's discourse analysis on reliefs in Panataran Complex, East-Java. Discourse leads to a new way for interpreting reliefs and opens new meanings for batik pattern that we have taken for granted, called kawung. Apparently, approaching artifacts as aesthetic representations is able to take to higher understanding of history and better appreciations for artifacts.
\end{abstract}

Index Terms-Aesthetic-representations, artifacts, kawung, discourse, foucault, Sangkan-paraning-dumadi.

\section{INTRODUCTION}

Indonesia as a nation-state is pretty young, being proclaimed as an independent modern state only in 1945. However, human civilizations in Indonesia have existed many centuries before she became a modern nation. In the island of Java alone, it is fairly easy to find the traces of old Javanese societies. They can be found scattered all over the island; some are still in pretty much good condition, such as Candi Borobudur, a Buddhist temple, built in the $8^{\text {th }}$ century by one of the rulers from Syailendra dynasty, or Candi Prambanan, a Hindu temple built in the Sanjaya dynasty around the same era [1], [2]. Not many monumental artifacts survived time as good as those two historical sites, most did not sustain and lost forever. There is one in East-Java that is worth studying before it disintegrates further. It is now popular as Candi Panataran in Blitar, East-Java. It used to be called Candi Palah, at one point of a time, according to the inscription neary. A candi is a religious temple for the Hindus or Buddhists; it functions as a mosque or a church in the modern days. Unlike candi Borobudur, which is still used as a place to hold religious rituals for some Buddhists, Panataran is a dead monument [3]. It is no longer used during religious important days as a place for worship or to do rituals. Nevertheless, this fact does not decrease its value as an

Manuscript received May 22, 2015; revised July 24, 2015.

The authors are with Bandung Institute of Technology (ITB), Faculty of Art and Design, Indonesia (e-amil: lhsetiono@gmail.com). important historical and cultural monument. Being the largest candi in East Java so far, its reliefs are significant critical for the people and the history of East Java. Unfortunately, these reliefs start to lose their forms, mostly due to natural deterioration, weather condition, and Gunung Kelud's volcano ashes. The mountain repeatedly erupted, and its ashes were often blown toward Panataran, creating significant damages. It would be very unfortunate if the meanings and values behind these reliefs be forgotten before their significance can be appreciated and preserved. Those reliefs might carry some important messages for this era and the generations after.

\section{ApProAches to StUdy HistoricAl ARTIFACTS}

The most common approaches to study artifacts in Indonesia until now are through either Archaeology or Anthropology. Archaeology approach studies the material properties of the artifacts in a positivistic manner: their elements, dimensions, compositions, geographic locations, and other positivistic measures. This approach is often called the classical or processual archaeology, because apart from looking at the material properties of the artifacts, classical archaeology also studies the processes that were involved in the production or distribution of the artifacts. Archaeology is very useful for documentation or experimental purposes, because it is objective, empiric and scientific in the process of investigation. On the other hand, this approach seems to be too specific and limited for further analyses. It is a non-interpretive approach, which focuses on the visible and sayable [4]. The other approach, anthropology, is a study of cultural variables of a society. It looks at symbols, languages, rituals, and some other cultural products of the society for social and/ or political investigations. Many scholars believe that anthropology is too wide or too holistic as an approach to study historical and cultural artifacts, as culture is a highly complex and broad area (see Fig. 1).

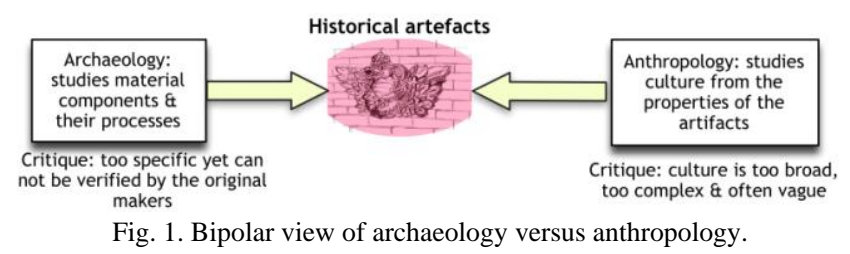

These two (2) branches of knowledge approached historical artifacts from a bipolar view; each had its own specification and benefits, yet meaningful interpretations of the past were not easy to find. In 1980's, Michael Shanks and Christopher Tilley developed a different approach to archaeology and named it social or interpretive archaeology [5]. It studies the contextual dimensions of the artifacts, such as the political and social influences, which may not be 
obvious at the beginning; this is often called post-processual archaeology. Some opponents to this approach were not enthusiastic because they believe that it tended to oversimplify the research. It focuses only on selective issues, such as gender, wealth distribution, and power-relation. When the pursuit to understand the past keeps rising, inter-disciplinary studies start to participate in the quest to find deeper meanings from these artifacts, including visual arts studies. Visual arts perspective looks at objects from a fresher point of views, as the representations of the artists' creative souls, being projected into materiality. These aesthetic representations carry within them realities of the past, including political ideologies, social arrangements, and cultural symbolisms of the past. They can be interpreted through discourse. This paper wishes to show that discourse analysis is a powerful tool to study historical and monumental artifacts as representations of the artists.

\section{A. Discourse Analysis Is Appropriate for Finding Meanings from Historical Artifacts.}

Originally, Foucault's discourse analysis was popular amongst linguists to explain what is hidden beneath the formation of a word or relationships between words and society. Later, scholars from other disciplines used this mode of analysis to study other forms of texts, including images. Visual arts perspective sees that discourse analysis is appropriate for studying historical or cultural artifacts, because firstly, historical or cultural artifacts are texts, which in some points are communicative. They are also representations, since they are the products of carefully constructed thoughts during the time of production. Almost all reliefs in Indonesia can be considered as artworks and representations. They are then discursive objects and can be analyzed by discourse [4].

Secondly, there is no final interpretation to history and culture. History and culture are always on the making; they are never final. Discourse sees this as a fertile ground for open interpretations and new knowledge. Discourse would continuously seek for new meanings until they can be accepted universally. This tradition is adopted from Gadamer's hermeneutics [6]. In this way, discourse does not try to find solution or look for one final answer but to open a contextual starting point for further discussions until knowledge about the discursive object can be formed. Historical and cultural artifacts need this approach to open new possible meanings that can be useful for further analysis.

Thirdly, discourse allows attention to contradictions; in fact, it flourishes in contradictions, disruptions, discontinuities, and irregularities, which some modes of analysis tend to ignore. Most analysis focuses on coherence, consistencies, and continuities in order to establish a pattern of causal-effect relationship. Discourse analysis look for patterns of relationships without an obligation to make coherent final statements. In this way, discourse analysis is not limited by technicalities or constraints which other research methods obliges.

\section{B. How Discourse Analysis Find Meanings in Artifacts}

Tatyana Bondarouk \& Huub Ruël, who used discourse analysis in an information system research in 2004, believed that even when discourse may appear incomplete, ambiguous, contradictory, and double-edged, it is also powerful. Precisely how discourse does this? Discourse proposes to look for patterns: patterns of social relationships, power relationships, and other relationships. Those patterns work like statements, which have structures, coherence, and rules obeyed by the society of that particular era. Through those patterns we learn about relationships between the texts, in this case the artifacts, and their contexts [7]. These contexts could be local or general, or specific or universal [6].

The objective for studying historical artifacts through discourse is to use the past to understand more about the present and gain some new insights [4]. It is also looking at history with curiosity to find new information of what we have been taking for granted [8]. The purpose of this discourse is not to determine the progression or regression of human civilizations, but to show that the past and the present have different understanding, interpretation and critical thinking processes. Thus, discourse analysis is appropriate to study reliefs in Panataran Complex.

\section{CANDi PANATARAN}

Some of the reliefs in Candi Panataran are still relatively in its original form. There is no modern alteration to them. Although most of these reliefs are not in good condition, there are some forms that are still worthy to be scrutinized.

\section{A. Location and Its Surrounding}

The site is located near the city of Blitar, East Java, at approximately $8^{\circ} 00^{\prime} 57^{\prime \prime} \mathrm{S} 112^{\circ} 12^{\prime} 33^{\prime \prime} \mathrm{E}$, with altitude of 450 meters above sea level. The total area of Panataran complex is around 12,000-13,000 square-meters. The complex is surrounded by modern houses and is situated very close to a main road. The complex used to have many monumental buildings; however, only some of them survived, including: 1). Candi Utama or Main three-storey temple, 2) Candi Naga or Dragon temple, 3) Pendopo or Terrace, 4) Ganesha temple, and other insignificant remains. [9]. An active volcano named Gunung Kelud is located not far from the complex. It is often erupted and its last one was in February $14^{\text {th }}, 2014$. This eruption was thought to be the biggest eruption of Kelud so far and its ashes might have done severe damages to the artifacts in the complex. Consequently, it is rather urgent to study and preserve the existing artifacts before they deteriorate further (see Fig. 2).

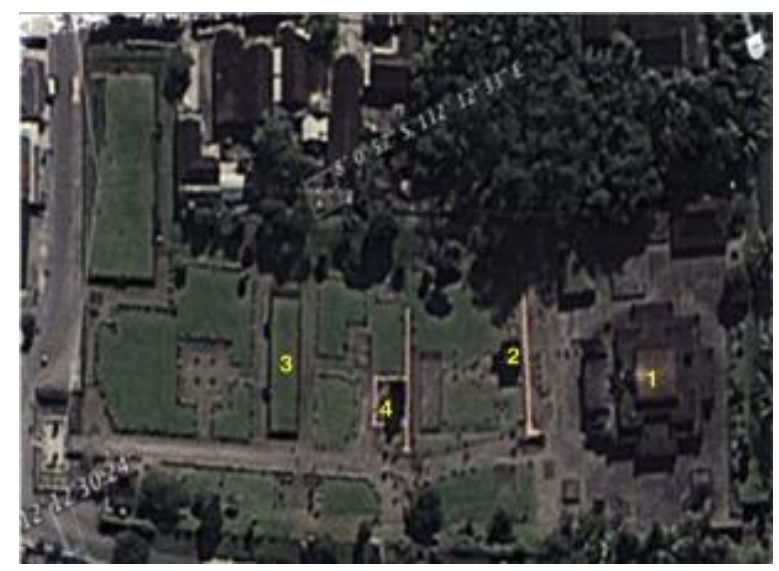

Fig. 2. Panataran complex [9]. 


\section{B. Candi Panataran: East-Javanese Archaeological Site}

Sir Thomas Stamford Raffles found Panataran complex during his expedition to Java around 1815. He was a British governor in Java during the colonial era, before the Dutch occupied Java. Raffles often compared Panataran to Borobudur and Prambanan, but even then, Panataran was not considered a significant temple; perhaps because they were not in good conditions when he found this complex. However, he made a note that the artworks which he found there were exquisite, amazing and deserve closer attention [10].

Panataran is the largest historical complex in East Java. So far, no valid indication of the year that this complex was built. There are few dates written in old Javanese on kalamakaras, the gates with the head of a fanged face, believed to be a symbol for the guardian of time. Inscriptions with years of 1119 Saka or 1197 AD; 1214 Saka or 1319 AD; 1291 Saka or 1369 AD; 1297 Saka or 1375 AD, and 1337 Saka or 1415 AD are found around the candi, carved in various places [3]. However, these inscriptions should not be automatically interpreted as the year of the construction. These dates could be the dates of visitations by some royalties or the dates of big commemoration being held there [11]. After all, candis were the place where important religious ceremonies were usually held, in the old eras (see Fig. 2).

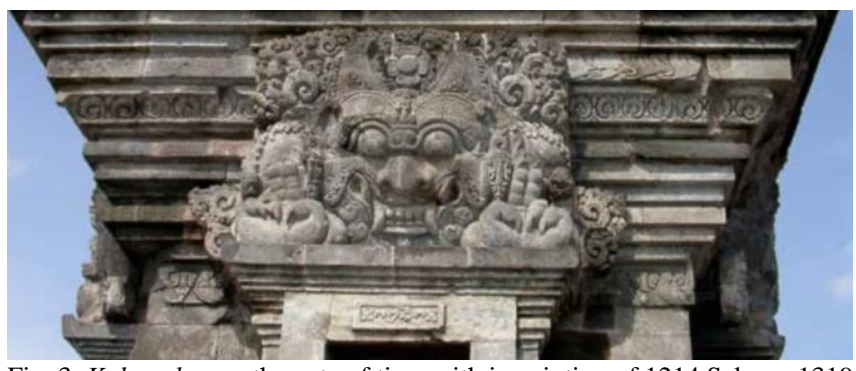

Fig. 3. Kalamakara - the gate of time with inscription of 1214 Saka or 1319 $\mathrm{AD}[12]$.

\section{Physical Characteristics of the Reliefs}

Almost all historical artifacts in Candi Panataran are made of mountain stones. Most are no longer in good condition. Some damages can easily be noticed; they might have been caused by natural degradation, or natural causes such as volcano's ash from Kelud Mountain nearby, or damaged by irresponsible and ignorant visitors. Similar to the characteristic of most Southeast Asian temples, there are many reliefs carved in the temple's walls. Raffles described the reliefs as showing highly artistic and aesthetic works, "menunjukkan sebuah tingkatan seni dan cita-rasa", [10].

Categorizing the remaining reliefs left in Panataran complex, there are at least three (3) different types: 1). Sculptures or full-reliefs; 2). Bas-reliefs or low-reliefs; and 3). The combination of both.

1) Full-reliefs are reliefs attached to a base on the ground. This kind of reliefs commonly called sculpture. This technique was most common in ancient civilizations, such in Europe, Egypt, and also China. In Panataran complex, full-reliefs can be found scattered around but they are not many left. The full-reliefs might not be standing in their original position, but they were still significant, in size and details. When Raffles found Panataran complex in 1815, there might have been much more full-reliefs in the location, but the smaller ones were easily deteriorated, damaged or even taken out of site. The remaining ones are too big or to heavy to be carried or transported, and commonly referred as arca dwarapala. Dwarapala is the name given to sculpture of gatekeepers, generally positioned on both sides of a stairway toward the front door in pairs. However, to this study full-reliefs in Panataran complex were not dwarapala; firstly, because they were not in pairs. Secondly, dwarapalas were never accompanied by smaller human-like figures on their sides. (see Fig. 4a \& Fig. 4b. Full-reliefs in Panataran Complex).
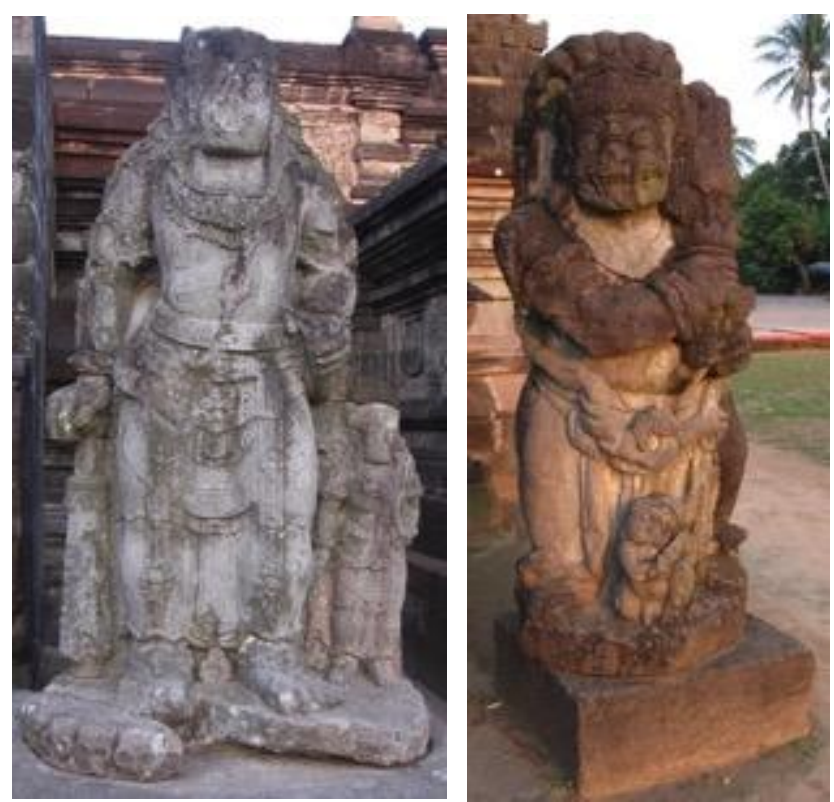

Fig. 4a \& 4b. Full-reliefs in panataran complex [12].

2) Bas-reliefs or usually called low-reliefs are reliefs carved on the wall. The technique of carving bas-reliefs is very tiresome because it requires the sculpture to chisel the surface of the stones and created background so that the unchiselled parts seem to be raised in intended forms (see Fig. 5a \& Fig. 5b. Examples of bas-reliefs in Panataran Complex). This technique used to be very common in Southeast Asia, mostly used in the period of Hindu-Buddhism. In fact, reliefs in Candi Borobudur were mostly bas-reliefs, narrating the birth of Buddha, carved into 2672 panels of mountain stones [13].

In Panataran complex, bas-reliefs can be found almost in every major parts of the candi: 1). Bas-reliefs encircle the terrace that has a measurement of length 29,05 , width 9,22 , and height 1,50 metres. 2). Bas-reliefs are carved in the three-storey square-shaped main candi, measured 30,06 meter each side \& with 7,19 meter in height. Bas-relief on the left (Fig. 5a) depicts an older woman talking to a distraught young girl and the one on the right (Fig. 5b) two grown men, one carrying a box while the other one watches him on the Terrace and many others. Most bas-reliefs were very detailed and beautifully carved, although most had already showed signs of decay.

Some studies explained that the reliefs on the Terrace were depicting the folklores of the era, such as the story of Sang Satyawan, Sri Tanjung, Bubuksah-Gagang Aking, Ramayana, 
Kresnayana, Pemburu or The Hunter, Kura-kura yang Sombong or The Arrogant Turtle, and Lembu \& Buaya or The Cow and The Crocodile [3]. Whether or not these reliefs represent foklores should be questioned because there are some bas-reliefs, which do not narrate local folklores, but portray real-life events during that era [11]. These bas-reliefs are aesthetic representational works. They contained some intentional messages and did not exist merely for aesthetic purposes. As in many representational works, there were rules that affected the artist and the society, which might have been represented in these reliefs. Some of them were hidden and waiting to be explored.
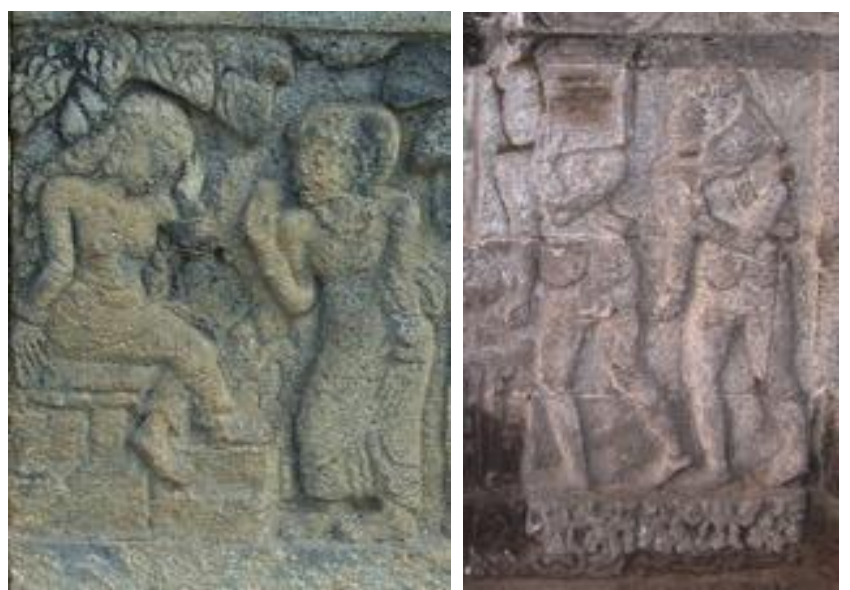

Fig. 5a \& 5b. Examples of bas-reliefs in panataran [14].

3) The combination of full-relief and bas-reliefs can be found in Candi Naga in Panataran complex. It is called the Candi Naga, meaning the Dragon Temple, because it has a bas-relief of a dragon or a snake around it (see Fig. 6). Candi Naga is measured 4,83 meters in width, 6,57 meters in length, and 4,70 meter in height. There are eight (8) figures carved on the wall of this rectangular-shaped monument, which uphold the body of the dragon with their hands/arms. To this research, Candi Naga seems to be more a full-relief with bas-reliefs on it. The center of Candi Naga is hollow and the top is flat, which are not the characteristics of most candis in Java. The base is rectangular, which does not follow the common measurement of a candi as a temple for worship, which is mostly a square, symbolizing the belief that the earth is round with equal division, each being ruled or protected by a god, as in the principle of Langlangbuwana or pangider-iderbumi [11]. Rahardjo associated Candi Naga with Samudramanthana, the folklore of the gods and the giants who stirred the sea in order to find the holy water, amerta, which can give everlasting life. Samudramanthana is popular in East Java. It is also depicted in Candi tugu Ampel Gading in Malang, Sirah Kencong Blitar and Kesiman Tengah [15]. Wisnoewhardono (1995) assumes that Candi Naga is a part of the temple to keep sacred properties of the gods, such as keris and other sacred goods and it was used for the rituals of pemasupatian or for the request of mystical power. He associated this function because he saw Candi Naga was very similar to Pura Kehen, located in the village of Bangli and Pura Taman Sari in the village of Klungkung [3] (see Fig. 6).

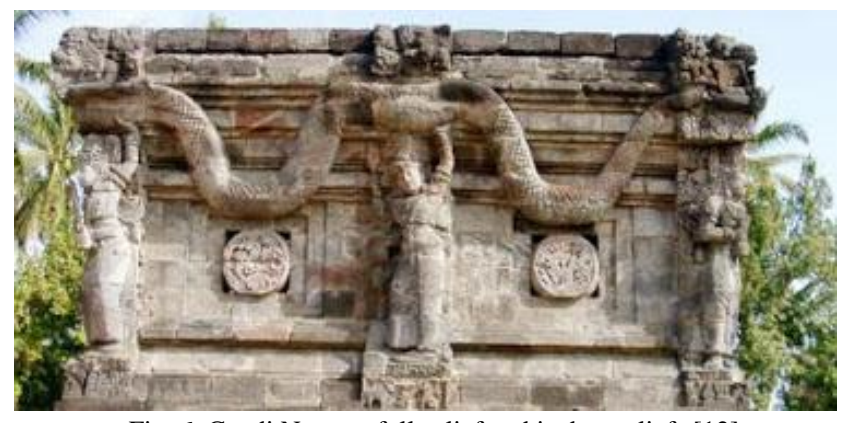

Fig. 6. Candi Naga as full-relief and its bas-reliefs [12].

The explanations above are the information we know so far about historical artifacts in Panataran from the scholars using, mostly, archaeological methods. They were able to show that these artifacts were the products of human activities during an era in the $11^{\text {th }}$ century society (taking the dates carved on some of the artifacts). However, they are rather descriptive and non-interpretive descriptions of the artifacts' material properties. There is still more to these artifacts that can be learned. Foucault's discourse is able to dig deeper and seek for hidden meaning by using second-order thinking process and judgment.

\section{FINDING AND DISCUSSION}

\section{A. Distinctive Patterns of Relationships Beneath Aesthetic Representations of the Artifacts}

In order to use Foucault's discourse analysis, we must assume that the discursive objects are representations, thus they are texts to be deciphered. In Foucault's perspective, artifacts in Panataran complex were documents that turned to become monuments through history [8]. As documents, those artifacts conserve messages about specific relationships, which patterns can be clearly seen, such as:

1) Representation of relationships with deities in full-reliefs can be seen from Fig. 4a \& Fig. 4b. the two (2) examples of full-relief in Panataran Complex, above. The significantly different size between the small and big figure in a single full-relief is the first opposition that catches attention. Full-reliefs were normally a projection of a single entity, be it a statue of dwarapala or a gatekeeper, a personification of a god or goddess, or a person. These two forms are eye-catching precisely because they are non-single and placed together, in dichotomy of size: large and small. They are not only representing the existence but more projections of relationship between two (2) entities. The entities are highly likely to be a human as the small one and his/her protector or superior as the big one. The headdress, arm and wrist bracelets of the big figures show that the deities are rich and powerful beings, which are superior compare to the small figures beside them. In the case of full-relief as in image below (7a. Relationship between female protector and protégé), the sash, headdress, arm-bracelets and other accessories indicated that the protector and the protégé were both royalties, or in high-ranking hierarchical system. Gada or beating stick in this full-relief was pointing down, signifying the relationship was non-violent, harmonious and close. 


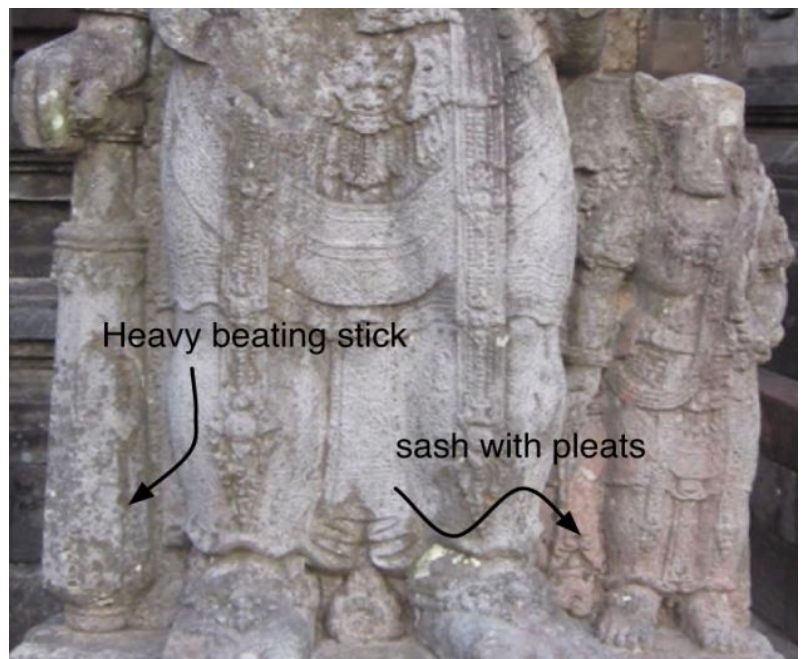

Fig. 7a. Relationship between female protector and protégé [14].

The relationship between the female protector and protégé in Fig. 7a above is very different with the relationship in the full-relief below (Fig. 7b. Another relationship between a human and a deity). Gada or the beating stick was pointing upward, as if it was ready to strike, while the smaller figure kneeled down in subservient position. The sash of the large figure was knotted with the head of a serpent on it, and the fang showed that this figure was not a protector as in female figure above but more into a superior being who watch over the smaller figure, subordinate to him. The headdress of the smaller figure and the lack of arm bracelet showed that he was not a royalty; perhaps he was an immigrant in the area (the head of snake is usually the symbol for the guardian of the earth).
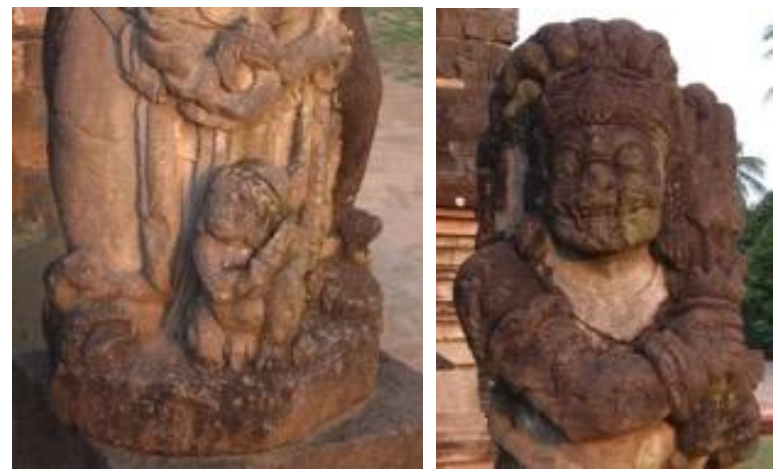

Fig. 7b. Another relationship between a human and a deity [14].

These two full-reliefs revealed a pattern of relationships between human and the unseen immaterial beings around $11^{\text {th }}$ century of East Java, (the large figures are unseen \& immaterial are assumptions unless there was some kinds of material evidence found, which indicated that they existed as material beings). The artists who built these full-reliefs, or the authority that instructed them, must have believed that deities had forms similar to human beings. The old Javanese people used to believe and acknowledge the existence of divine protectors or guardian angels, and called them pemomong, which means the one who takes care and protects. There is a difference in the concept and attitude of the old Javanese people between the followers of Hindu and Buddha toward these pemomong [16]. In Hinduism, these protectors could have physical forms and are usually associated with the gods or goddesses. In Buddhism, the protectors did not have to be represented by physical forms; they could appear as concepts or understanding. The full-reliefs here could have some Hindu influences within them. This could serve as a validation that Hinduism was dominant in East Java around $11^{\text {th }}$ century and their value systems must have been conserved in Panataran complex. Reliefs were indeed contained many stories that were waiting to be discovered.

2) Panataran complex is the host for other kind of representations from the past. The wall of pendopo (the terrace) in Panataran complex, measured 29,5 x 9,22 x 1,50 meters (marked number " 3 " in the Fig. 2. above), are filled with bas-reliefs. Some bas-reliefs in Panataran complex are still showing decipherable forms, while most are totally illegible, mostly due to the severity of their damages (see Fig. 8).

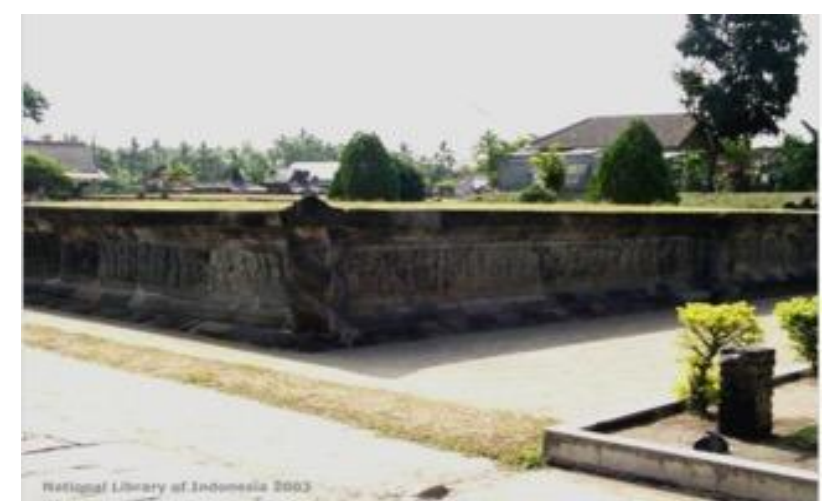

Fig. 8. The Terrace (Pendopo) in Panataran Complex [12]

Apart from the head of the snake and snake body encircling the platform of the terrace, there is not much symbolism in this Terrace. (Fig. 9) There is no traceable opposite sizes in the reliefs. Most of the bas-reliefs here are depicting the activities of human beings, in interactions with other fellow human beings, such as the portrayal of four (4) ladies in walking poses with horses and palm-trees, as below:

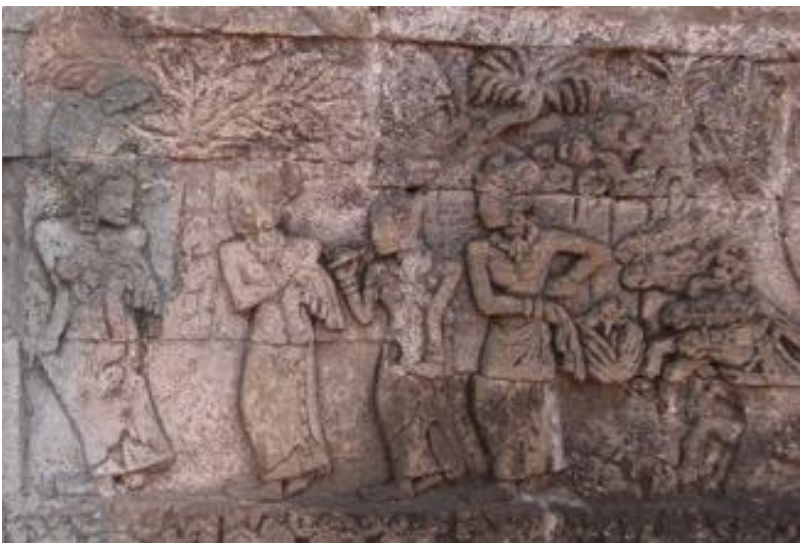

Fig. 9. Realistic representation of Javanese lifestyle [14].

Their attire was similar to those of the old Javanese people: strapless top to cover the breasts (kemben), long batik cloth wrapped around the waist (jarik), sashes (selendang), and headdresses. Additional details such as bracelets, necklaces, earrings, and other jewelries showed that these ladies were nobilities, compare to the bas-reliefs of the two maids on the right of Fig. 10. below.

Other bas-reliefs in the terrace illustrated similar characteristics; they represented common lifestyle of the people, in East Java during $11^{\text {th }}$ century and their relationship 
with each other. These realistic representations have been interpreted as folklores, as explained above. Those interpretations must be reviewed if we want to understand more or if we would like to reject existing some explanations, which we already have been comfortable with. Unfortunately, not many are still in good conditions for new interpretations.

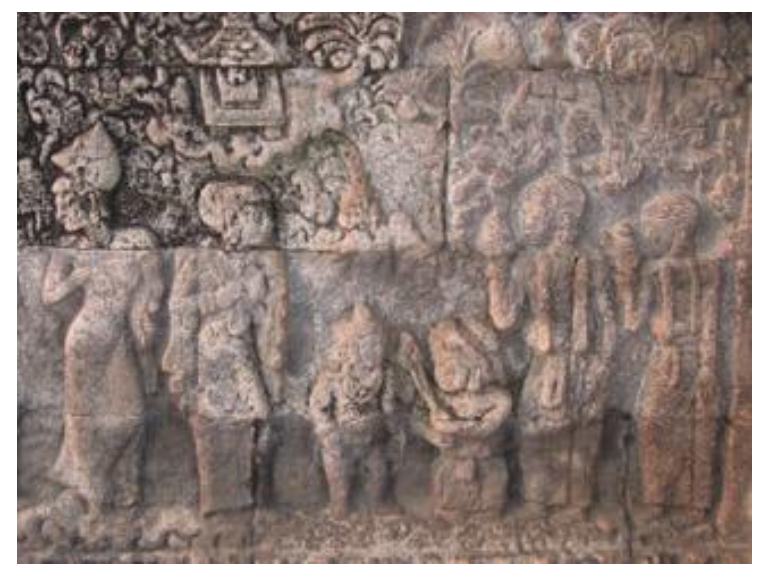

Fig. 10. Bas-relief representing young nobles playing together, with the significant others on the left and maids on the right [14].

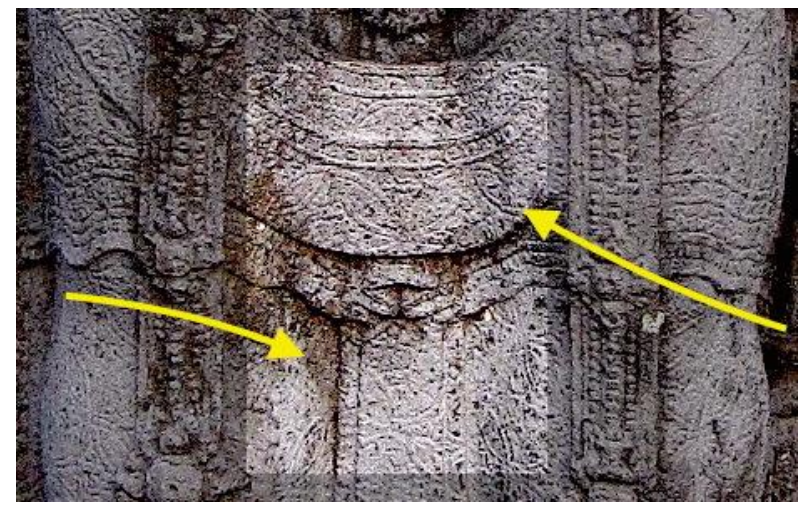

Fig. 11. Kawung carved in the full-relief [14].

\section{B. Gender Position Revealed}

We go back to the discussion of the full-reliefs of humans and deities. Fig. 7a. Female protector and Female protégé represented a harmonious relationship between them. On the other hand, Fig. 7b. showed the relationship between a male and its deity as non-equal position with potential violence. It was more like a superior-subordinate position. These two relationships revealed the position of power, then. The relationships between the royalties and their deities were more harmonious and non-violent than between the commoners with their superior deities. The power relationship represented by these full-reliefs was more based on social standing rather than based on gender. The position of power cross-gender was not found. This could mean that a male deity was not more powerful than a female deity and the male protégé was not more powerful than female protégé. In other word, a female was not considered inferior than a male. In fact, the full-relief (Fig. 7a.) might indicate that the small figure was a queen as history also acknowledged than there were great Javanese queens in the past. Accordingly, it is with confident to say the East Javanese society was hierarchical during the $11^{\text {th }}$ century, and it was a class-based society with some kind of oppression toward the non-royals or commoners.

\section{Discourse Analysis on "Kawung” Pattern}

Foucault's discourse analysis is not only useful to study relationships from what are visible on the historical artifacts, but is also capable to find the history of idea, based on the visible [8]. Further examination on the full-relief (Fig. 7a) showed that the artist's carved another detailed pattern in the figure of the protector. A close up at the long batik cloth (jarik) worn by the female protector, we will see a pattern that is still in existence until now. There is no trace of Kawung being worn by the smaller human figure. The pattern is now called kawung (see Fig. 11).

For Foucault, if a similar pattern is repeated in the same field and consistently contain enunciation regularities, then it may have deeper meaning than what appears in the surface [8]. Moreover, this pattern survives more than a thousand years, despite the political, social and cultural changes that the Javanese people had gone through (see Fig. 12). a)

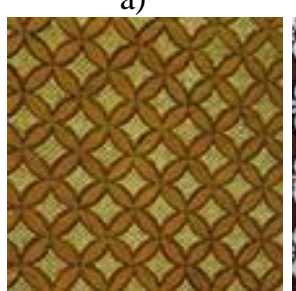

b)

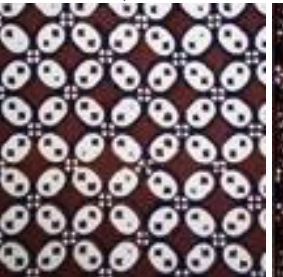

c)

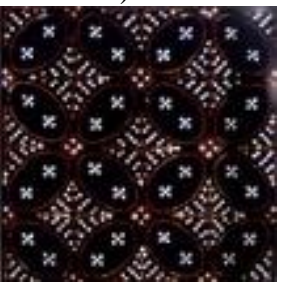

Fig. 12. Variations of kawung nowadays [17].

By consensus, kawung is considered a very old pattern and is most often associated with palm-toddy fruits or kolang-kaling (arenga pinnata) [18]. Not many people question the validity of this reference. This association had been taken for granted and had not been challenged. Even though most batik patterns do represent symbolic relationships with nature, the association for kawung should be seen as invalid, because not all palm-toddy fruits have four (4) chambers, many have only three (3) chambers. The reference to palm-toddy fruits becomes weak, vague and too speculative. This condition is precisely an ideal condition for discourse [8] (see Fig. 13a, Fig. 13 b). a)

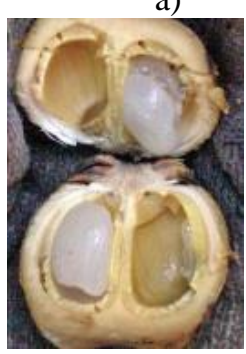

Fig. 13. Palm-toddy fruits [19]. b)

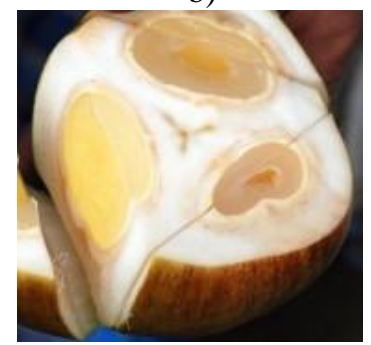

Discourse analysis called for a second-order judgment by taking prepositions that have existed; for kawung, they would be:

1) That this pattern is associated speculatively to palm-toddy fruits.

2) That this pattern was sacred and used to be exclusive only for the King and his immediate family, prior to $16^{\text {th }}$ century. Only after $16^{\text {th }}$ century, other nobilities could use this pattern.

3) That as tradition, kawung is now frequently used to 
cover a deceased (lurup). There is no explanation of why or when this tradition appeared for the first time.

4) Kawung had existed since $11^{\text {th }}$ century being worn by the representation of a deity, preserved in the full-relief at Panataran Complex.

First, discourse started with incoherence [8]. In this case, the association with palm-toddy is inconsistent with reality, thus the association should be questioned. Then, we must separate the contradictions, including irregularities, disruptions, or mistakes from discursive object, the pattern of kawung. Here we notice that there is a history of discontinuity in the usage of kawung, from being very sacred prior to $16^{\text {th }}$ century, to less sacred after $16^{\text {th }}$ century, to the present days: kawung can be used by anyone. The fact that kawung is still being used as lurup to cover the deceased can be a sign that there is another meaning to kawung which tradition tries to preserve, in its repetition. Foucault mentioned that "tradition enables us to isolate the new against a background of permanence and to transfer its merit to originality" [8]. The Javanese tradition of using kawung as lurup may contain more meanings than a mere representation of palm-toddy fruit. The tradition had made this pattern survived historical irruption, discontinuities, and social, political or cultural changes.

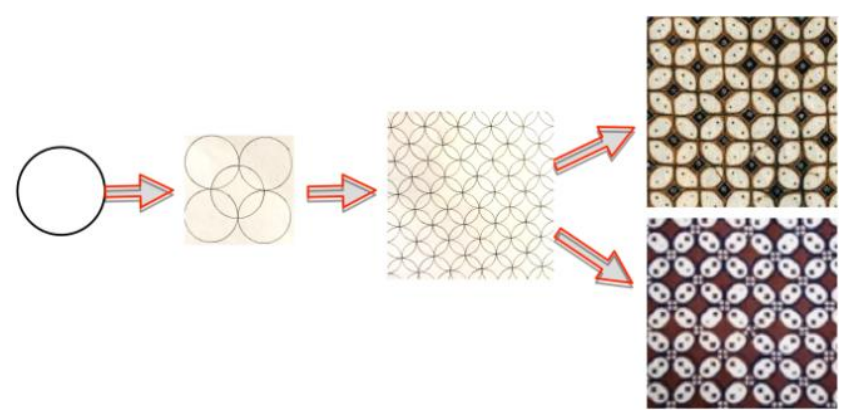

Fig. 14. Kawung and its foundation.

\section{Other Interpretation of Kawung}

Repetition makes a pattern, and repetition is very important to any analysis. We will find a single basic pattern if we break down the pattern of kawung carved in full-relief in Candi Panataran. The pattern of kawung is actually a repetition of a circle, configured in a systematic way, (look Fig. 14. Kawung and circles). A circle is universally associated with infinity, a complete cycle, perfection, cosmic, celestial, planet, sun, moon, and other things that are related to divinity [20]. This is not only to confirm the artist in Panataran complex's reference of the full-relief to a supernatural being, but it also leads to the Javanese concept of the self. The Javanese believe that a human is never born alone to this world. He/ she has divine protectors who accompany him/ her during his/ her journey on earth, known as sadulur papat kalima pancer. His/her four (4) invisible quadruplet-siblings (sadulur papat) serve as supernatural protectors or guardian angels; the center circle, number five is the self (kalima pancer). This concept is still very much alive until now for some traditional Javanese, but the responds and attitudes toward this concept vary. Some Javanese believe that these four circles are immaterial beings serving a human being as guardian angels, but there are also some Javanese who believe that these four entities were part of the baby's body, including the placenta and the umbilical cord (kakang kawah adi ari-ari). It will take another discourse to discuss in great detail on this concept and it is not relevant to this study. The reference of kawung to the concept of guardian angels is the relevant one.

When a person dies, kawung is used as a symbol that the deceased goes back to a supernatural realm, to his/ her origins, which is a process, which is called sangkan paraning dumadi. Thus, kawung in a cloth symbolizes the closeness to divinity (see Fig. 14).

\section{CONCLUSION}

Discourse, as a method of analysis, might have seemed imperfect for some disciplines, because it does not occupy mathematical logic or logic that are commonly used in the academic world. It relies heavily on symbolic logic. But, Michel Foucault (1926-1984) proposed a method, called discourse, and was successful in making it into an effective method for non-mathematical based researches. Discourse is useful as a starting point to open new interpretations or new insights to historical artifacts, as this study reveals. Through discourse, visual art perspective is able to approach historical artifacts not only as the products of skillful artists of the past but serve as the container for the artists' souls, interests, thought processes, desires, attitudes, and values. To Foucault, artifacts were also representations and worked as documents in the past, which contained socio-politico and social-cultural information within. But, these monuments are only worth as much as our understanding about them. Foucault encouraged the exploration of meanings beneath these representations to understand them better [8]. When Foucault's thoughts and method on discourse are applied to Panataran Complex, the results are amazing. Historical artifacts there do carry deeper meanings than mere symbolism of folklores. A single artifact can reveal the history of kawung, the perception of relationships between human beings and deities, and the connection of concepts which some Javanese treasure highly yet knew so little about: sadulur papat kalima pancer and sangkan paraning dumadi. A couple of similar artifacts could reveal the society's perceptions on power relationships: between social classes, gender, and even with deities. A pattern of relationships, represented as bas-reliefs on the Terrace, would reveal social relationships amongst human beings during the time of production. Although this study is not perfect, it has been able to open up new understanding and new appreciation toward historical artifacts in Panataran Complex. Hopefully, with the new understanding, new interests and motivation for preserving other historical artifacts will increase.

\section{REFERENCES}

[1] Borobudur temple compounds. [Online]. Available: http://whc.unesco.org/en/list/592

[2] Prambanan temple compounds. [Online]. Available: http://whc.unesco.org/en/list/642

[3] S. Wisnoewhardono, Memperkenalkan Komplek Percandian Panataran, Mojokerto: KPN Purbakala, 1995.

[4] G. Kendall and G. Wickham, Using Foucault's Methods, London: Sage Publications, 1999.

[5] M. Shank and C. Tilley, Social Theory and Archaeology, Albuquerque: University of Mexico Press, 1987. 
[6] M. Jorgensen and L. J. Phillips, Discourse Analysis as Theory \& Method, London: Sage Publication, 2002.

[7] T. Bondarouk aand H. J. M. Ruël, "Discourse analysis: Making complex methodology simple," in Proc. the $12^{\text {th }}$ European Conference on Information Systems (ECIS), 2004, Turku Finland.

[8] M. Foucault, The Archaeology of Knowledge, Milton Park: Routledge Classics, 1969.

[9] Picture Taken from: Google Earth, Candi Panataran

[10] T. S. Raffles. The History of Java. (Hamonangan and Simanjuntak, Trans, Yogyakarta: Penerbit Narasi, 2008, pp. 382-384.

[11] L. H. Setiono, "Tracing the $11^{\text {th }}-12^{\text {th }}$ century's of Asia's connectedness. Learning from Candi Panataran reliefs," presented at the International Academic Forum, Osaka, Japan, during the Asian Conference on Arts \& Humanities 2013, April 4-7, 2013., pp. 680-696.

[12] Picture: National Library of Indonesia. [Online]. Available: http://gpswisataindonesia.blogspot.com/2014/01/candi-panataran-blita r-jawa-timur.html

[13] Wikipedia.

Available: http://en.wikipedia.org/wiki/Borobudur

[14] Picture: Private Collection.

[15] Rahardjo, S. Peradaban Jawa. Dari Mataram Kuno sampai Madjapahit Akhir, Depok: Komunitas Bambu, 2011, p. 231.

[16] E. Sedyawati, Saiwa and Bauddha di Masa Jawa Kuna, Denpasar: Penerbit Widya Dharma, 2009, p. 90.

[17] Picture: owltowncollections. [Online]. Available: http://fitinline.com blogspot.com

[18] Picture: Marina Elphick. [Online]. Available: http://marinaelphick.com/2014/02/17/kawung-batik-motif/

[19] Picture.

[Online]. http://world-crops.com/asian-palmyra-palm/

Available:

[20] Catherine http//altreligion about com/od/symbol/s/geometric-Shapes/C htm.

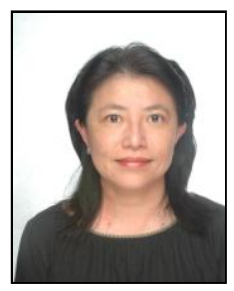

Lilly Harmawan Setiono was born in June 1962 in Bandung, Indonesia. She received her bachelor of science (B.Sc.) majoring in industrial psychology and mentoring in business administration in 1993 from California State University, East-Bay, California in 1993. She continued her education in Indonesia and obtained her magister sains (M.Si) in clinical psychology in 1999. Later, She went to University of Western Australia and obtained her master of criminal justice system (M.C.J.) in 2001. Lilly is now attending Bandung Institute of Technology (ITB), Faculty of Art and Design, for her doctorate degree with specialty in filmmaking. Her main research interest is on individual development using audio-visual as the medium. The topic of her dissertation is on visualizing personality and leadership using artifacts from $11^{\text {th }}$ century. Lilly's work experiences ranged from being a managing director in textile manufacturing, a head of human resources division, a consultant for individuals and corporations, a program designer for crisis intervention projects, and a scriptwriter for documentary films.

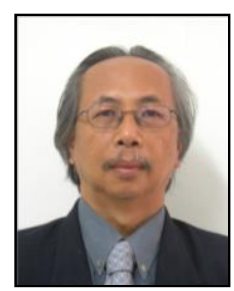

Setiawan Sabana was born in May 1951. is a professor for Art \& Design Faculty at Bandung Institute of Technology. He attained his undergraduate degree from Institut Teknologi Bandung (ITB), post-graduate degree from Northern Illinois University's Art Department, and doctorate degree from Institut Teknologi Bandung (ITB). Setiawan Sabana is a active member of the professorial committee in ITB, a productive fine-art artist, the Jury for many art-competitions, the keynote speaker for various events, and a prominent writer. He is also the recipient of awards and grants from Japan and South Korea and the honorary holder of Satyalancana Karya Satya, the most prestigious award from the Indonesian President. Galleries in Australia, Poland, Hungary, South Korea, Australia, and Jordan are the hosts for some of Sabana's arts. 